\title{
Sequential Evaluation of DNA Damage in Patients with Head and Neck Carcinoma Receiving Radiotherapy
}

Sivakumar M ( $\sim$ drsivakmc@gmail.com)

Thiruvannamalai Medical College and Hospital

Ariyanachi K

All India Institute of Medical Sciences

\section{Research}

Keywords: Head and neck carcinoma, radiotherapy, DNA damage, comet assay

Posted Date: June 1st, 2021

DOI: https://doi.org/10.21203/rs.3.rs-482544/v1

License: (c) (i) This work is licensed under a Creative Commons Attribution 4.0 International License.

Read Full License 


\section{Abstract}

\section{Background:}

Head and neck cancers account for about $30 \%$ of all cancers in India. The incidence rates of HNSCC in India are30/1, 00,000 for males and 10/1, 00,000 for females. The commonly used treatment modalities include surgery, chemotherapy and radiotherapy. Studies conducted in different types of cancers showed that there is anincreased primary DNA damage even before the commencement of treatment in cancer patients. The treatment modality will further induce DNA damage in addition to the already existing DNA damage.In normal healthy people, DNA damage is effectively repaired. However, in patients with carcinoma, chemo-radiation induced DNA damage is not repaired so effectively. Consequently, there is a high risk of secondary carcinoma by unrepaired damaged DNA.

\section{Methodology:}

In this study, the degree of DNA damage is assessed by comet assay technique in patients with head and neck carcinoma receiving radiotherapy and had complete regression of tumor following radiotherapy. The degree of DNA damage is compared according to the age, gender and associated risk factors of the patients.

\section{Results:}

The comet length parameter of post-RT sample is increased when compared to baseline sample. The head diameter parameter of post-RT sample is increased when compared to baseline sample. The percentage of DNA in head parameter of post-RT sample is decreased when compared to baseline sample. The tail length parameter of post-RT sample is increased when compared to baseline sample. All these findings are indicative of DNA damage following radiotherapy. Consequently, there is a high risk of secondary carcinoma by unrepaired damaged DNA.

\section{Conclusion:}

Patients with locally advanced head and neck carcinoma with complete tumor response following radiotherapy showed a sequential increase in the DNA damage. The co-existing risk factors and old age may increase the baseline DNA damage in the patients with head and neck cancers.

\section{Background}

Indian Subcontinent registers around 2,00,000 cases ofHead and Neck carcinoma each year and nearly about 80,000 of them are diagnosedas oral carcinoma(1). The pro-carcinogenic factors include alcohol in any formand consumption of tobacco in any form(2).Patients are classified into anatomic groups that are categorized from Ito IV based on the increasing severity of disease. Stage 1 denotes an earlydisease and stage 4 denotes a locally advanced disease with metastasis. Studies conducted in different types of cancers showed that there is anincreased primary DNA damage even before the treatment in cancer 
patients. The treatment modality will further induce DNA damage in addition to thealready existing DNA damage. Chemotherapy and Radiotherapy beingthe mainstay of treatment for locally advanced cancers induces DNAdamage in the target cells as well as to some of the normal cells in thesurroundings $(3,4)$.In normal healthy people, DNA damage is effectively repaired. But incancer patients, chemo-radiation induced DNA damage is not repaired soeffectively. Consequently, there is a high risk of secondary cancer byunrepaired damaged DNA $(5,6)$. This study is taken up to assess the degree of DNA damage by comet parameters in patients with head and neck carcinomawho had complete tumor regression after receiving radiotherapy.

\section{Methodology}

After approval from the scientific and ethics committee, this study was performed in the Department of Anatomy in collaboration with the Department of Radiotherapy, JIPMER. Selection of subjects was done from the Radiotherapy Department, JIPMER.Thirty five patients with stage II, III, IVA, histopathologically confirmed Squamous cell carcinoma of Head and Neck (lip, oral mucosa, nasal cavity, pharynx, paranasal sinuses, larynx) with KPS more than 70 attending radiotherapy OPD for treatment were included in this study.Patients with co-morbid conditions such as severe infections, blood dyscrasias, other genetic disorders, patients with abnormal liver function test, renal function test were excluded from this study.Previous $\mathrm{H} / \mathrm{O}$ chemotherapy, radiotherapy to any part before starting treatment were also exempted from this study. Under strict aseptic precaution, $1 \mathrm{ml}$ of heparinized blood was collected from the study participant after obtaining informed consent from them. The blood samples were collected as follow

1. 2 hours before the first dose of radiation

2. 2 hours after 10 th fraction of radiation

3. 2 hours after 20 th fraction of radiation

4. 2 hours after 30 th fraction of radiation

5. During 1st follow-up (1 month after completion of treatment)

All the samples were processed immediately and analyzed for DNA damage by single cell gel electrophoresis assay (Comet assay). To assess the DNA damage following comet parameters were used.

- Tail length

- Head diameter

- Comet length,

- Percentage of DNA in head

- Percentage of DNA in tail. 
The length of the comet tail was measured by using ocular scale fitted to the microscope. In order to avoid bias these parameters were employed on randomly selected 40 to 50 cells per subject.Categorical data obtained from the study was presented as frequencies and percentages. Chi square test was used to compare the categorical data. Normally distributed continuous data is presented as mean with the standard deviation. Comparison of continuous data has been done using independent student's $t$ test. All statistical analysis carried out with $p$ value $<0.05$ was considered statistically significant.

\section{Results}

The total sample size in this study is 35 .

\section{Age distribution:}

The details of age distribution of the cases in this study are shown in the Table I and Chart I.

\begin{tabular}{|ll|}
\hline Age in years & No. of cases (\%) \\
\hline $40-49$ & $9(25)$ \\
\hline $50-59$ & $16(46)$ \\
$\geq 60$ & $10(29)$ \\
\hline Total & $35(100)$ \\
\hline
\end{tabular}

\section{Gender distribution:}

The distribution of gender in this study are shown in the Table II and Chart II.

\begin{tabular}{|ll|}
\hline Gender & No. of cases $(\%)$ \\
\hline Male & $21(60)$ \\
\hline Female & $14(40)$ \\
\hline Total & $35(100)$ \\
\hline
\end{tabular}

\section{Risk factors}

The various risk factors associated with head and neck cancers are smoking, alcoholism, tobacco products, and the genetic predisposition. The risk factors found among the patients in this study were smoking, alcohol, tobacco chewing.

The details of the distribution of the cases in relation to the number of risk factors is shown in the Table IV. 


\begin{tabular}{|lccccc|}
\hline & \multicolumn{9}{c}{ No. of risk factors } & \\
\cline { 2 - 6 } Sub-group & 1 & 2 & 3 & No risk factors & Total no cases \\
\hline Complete tumour regression & 3 & 9 & 1 & 1 & 14 \\
\hline Residual tumour & 10 & 5 & 4 & 2 & 21 \\
\hline Total & 13 & 14 & 5 & 3 & 35 \\
\hline
\end{tabular}

\section{Baseline DNA damage}

\section{Age and Baseline DNA damage:}

Comet parameters of total comet length, head diameter, percentage of DNA in head, tail length and percentage of DNA in tail were recorded in all the age groups. The comet parameters of the baseline sample (before radiotherapy) among the various age groups are shown in the Table $\mathrm{V}$.

\begin{tabular}{|c|c|c|c|c|}
\hline \multirow[t]{3}{*}{ Comet Parameters } & \multicolumn{3}{|l|}{ Mean \pm SD } & \multirow[t]{3}{*}{ p value } \\
\hline & $40-49$ & $50-59$ & $>60$ years & \\
\hline & Years & Years & & \\
\hline Comet length $(\mu \mathrm{m})$ & $76.6 \pm 31.3$ & $55.3 \pm 29.2$ & $54.5 \pm 25.5$ & 0.125 \\
\hline Head diameter( $(\mu \mathrm{m})$ & $59.4 \pm 25$ & $46.5 \pm 23.6$ & $40.2 \pm 16.2$ & 0.018 \\
\hline$\%$ of DNA in head & $87.1 \pm 5.9$ & $87.5 \pm 5.4$ & $83.2 \pm 8.2$ & 0.242 \\
\hline Tail length $(\mu \mathrm{m})$ & $17.8 \pm 16.4$ & $9.7 \pm 10.1$ & $15 \pm 13.6$ & 0.082 \\
\hline$\%$ of DNA in tail & $12.9 \pm 5.9$ & $12.6 \pm 5.4$ & $16.8 \pm 8.2$ & 0.252 \\
\hline
\end{tabular}

\section{Risk factors and basal DNA damage:}

The comet parameters of the baseline sample in relation to the risk factors are shown in the Table $\mathrm{VI}$ and the Chart V. 


\begin{tabular}{|llll|}
\hline Comet Parameters & \multicolumn{2}{c}{ Mean \pm SD } & \multirow{2}{*}{ P value } \\
\cline { 2 - 3 } & Risk factors $<1$ & Risk factors $>1$ & \\
\cline { 1 - 2 } Comet length $(\mu \mathrm{m})$ & $66.9 \pm 31.7$ & $55.2 \pm 27.1$ & 0.172 \\
\hline Head diameter $(\mu \mathrm{m})$ & $53.3 \pm 24.5$ & $43.6 \pm 20.7$ & 0.279 \\
\hline \% of DNA in head & $87.5 \pm 7.7$ & $85.1 \pm 5.3$ & 0.292 \\
\hline Tail length $(\mu \mathrm{m})$ & $14.4 \pm 14$ & $12.3 \pm 12.5$ & 0.317 \\
\hline \% of DNA in tail & $12.5 \pm 7.7$ & $15.0 \pm 5.3$ & 0.273 \\
& & & \\
\hline
\end{tabular}

DNA damage after radiotherapy in patients with complete regression of tumor

The comet parameters within the patients having complete regression of tumor is shown in the Table VIII.

\begin{tabular}{|c|c|c|c|}
\hline \multirow[t]{2}{*}{ Comet Parameters } & \multicolumn{2}{|l|}{ Mediam (IQR) } & \multirow[t]{2}{*}{ p value } \\
\hline & Complete tumour regression & Residual tumour & \\
\hline Comet length $(\mu \mathrm{m})$ & 45.3(38.6-77.8) & $56.4(35.2-84.9)$ & 0.840 \\
\hline Head diameter( $(\mu \mathrm{m})$ & $40.2(37.6-55.6)$ & $37.5(27.9-66.6)$ & 0.329 \\
\hline $\begin{array}{l}\% \text { of DNA in head } \\
\text { (mean } \pm \text { SD) }\end{array}$ & $86.8 \pm 5.5$ & $85.7 \pm 7.1$ & 0.613 \\
\hline Tail length $(\mu \mathrm{m})$ & $6.5(3.0-14.1)$ & $7.9(3.7-23.0)$ & 0.400 \\
\hline $\begin{array}{l}\% \text { of DNA in tail } \\
\text { (mean } \pm \text { SD) }\end{array}$ & $13.3 \pm 5.5$ & $14.2 \pm 7.2$ & 0.652 \\
\hline
\end{tabular}




\section{a) Comet Length}

Comparison of comet length parameter of all the five samples in patients with complete regression of tumour is shown in Table IX and Chart VII.

\begin{tabular}{|c|c|c|c|c|c|}
\hline \multirow[t]{2}{*}{ Comet Parameters } & \multicolumn{5}{|c|}{ Mediam (IQR) } \\
\hline & Baseline & Post - RT1 & Post - RT2 & Post - RT3 & Follow - Up \\
\hline Comet Length & 45.3 & 114.5 & 116.5 & 116.9 & 67.9 \\
\hline$(\mu \mathrm{m})$ & $(38.6-77.8)$ & $(107.4-54.3)$ & $(107.5-146)$ & $(106.4-152.3)$ & $(54.5-82.6)$ \\
\hline \multirow[t]{2}{*}{$p<0.05$} & \multicolumn{5}{|c|}{ Baseline vs Post-RT1 } \\
\hline & \multicolumn{5}{|c|}{ Post-RT3 vs Follow-up } \\
\hline \multirow[t]{2}{*}{$p>0.05$} & \multicolumn{5}{|c|}{ Post-RT1 vs Post-RT2 } \\
\hline & \multicolumn{5}{|c|}{ Post-RT2 vs Post-RT3 } \\
\hline
\end{tabular}

The comet length parameter of post-RT sample [114.5(107.4-154.3) $\mu \mathrm{m}]$ is increased when compared to baseline sample [45.3(38.6-77.8) $\mu \mathrm{m}]$ with a $p$ value less than 0.05 .

There is a progressive increase in the comet length parameter of post-RT samples 1,2 and 3 , though it is statistically insignificant.

The comet length parameter of follow-up sample [67.9(54.5-82.6) $\mu \mathrm{m}]$ is decreased when compared to post-RT sample 3 [116.9(106.4-152.3) $\mu \mathrm{m}]$ with a p value less than 0.05 .

\section{B) Head Diameter}

Comparison of head diameter parameter of all the five samples in patients with complete regression of tumour is shown in Table $\mathrm{X}$ and Chart VIII. 


\begin{tabular}{|c|c|c|c|c|c|}
\hline \multirow[t]{2}{*}{ Comet Parameters } & \multicolumn{5}{|c|}{ Mediam (IQR) } \\
\hline & Baseline & Post - RT1 & Post - RT2 & Post - RT3 & Follow - Up \\
\hline \multirow{3}{*}{$\begin{array}{l}\text { Head diameter } \\
(\mu \mathrm{m})\end{array}$} & 40.2 & 66.0 & 65.3 & 62.2 & 56.6 \\
\hline & $(37.6-55.6)$ & $(54.7-81.9)$ & $(54.0-73.5)$ & $(51.6-85.7)$ & $(39.3-61.5)$ \\
\hline & & & & & ) \\
\hline \multirow[t]{2}{*}{$p<0.05$} & \multicolumn{5}{|c|}{ Baseline vs Post-RT1 } \\
\hline & \multicolumn{5}{|c|}{ Post-RT3 vs Follow-up } \\
\hline \multirow[t]{2}{*}{$p>0.05$} & \multicolumn{5}{|c|}{ Post-RT1 vs Post-RT2 } \\
\hline & \multicolumn{5}{|c|}{ Post-RT2 vs Post-RT3 } \\
\hline
\end{tabular}

The head diameter parameter of post-RT sample 1 [66.0(54.7-81.9) $\mu \mathrm{m}]$ is increased when compared to baseline sample [40.2(37.6-55.6) $\mu \mathrm{m}]$ with a $p$ value less than 0.05 .

There is a progressive decrease in the head diameter parameter of post-RT samples 1, 2 and 3 , though it is statistically insignificant.

The head diameter parameter of follow-up sample [56.6(39.3-61.5) $\mu \mathrm{m}]$ is decreased when compared to post-RT sample $3[62.2(51.6-85.7) \mu \mathrm{m}]$ with a p value less than 0.05 .

\section{C) Percentage of DNA in head}

Comparison of \% of DNA in head parameter of all the five samples in patients with complete regression of tumour is shown in Table XI and Chart IX

\begin{tabular}{|c|c|c|c|c|c|}
\hline \multirow[t]{2}{*}{ Comet Parameters } & \multicolumn{5}{|c|}{ Mediam (IQR) } \\
\hline & Baseline & Post - RT1 & Post - RT2 & Post - RT3 & Follow - Up \\
\hline$\%$ of DNA in head & $86.8 \pm 5.5$ & $79.6 \pm 7.8$ & $75.0 \pm 10.4$ & $73.2 \pm 10.3$ & $84.2 \pm 6.7$ \\
\hline \multirow[t]{2}{*}{$p<0.05$} & \multicolumn{5}{|c|}{ Baseline vs Post-RT1 } \\
\hline & \multicolumn{5}{|c|}{ Post-RT3 vs Follow-up } \\
\hline \multirow[t]{2}{*}{$p>0.05$} & \multicolumn{5}{|c|}{ Post-RT1 vs Post-RT2 } \\
\hline & \multicolumn{5}{|c|}{ Post-RT2 vs Post-RT3 } \\
\hline
\end{tabular}

The percentage of DNA in head parameter of post-RT sample $1(79.6 \pm 7.8)$ is decreased when compared to baseline sample $(86.8 \pm 5.5)$ with a $p$ value less than 0.05 . 
There is a progressive decrease in the percentage of DNA in head parameter of post-RT samples 1, 2 and 3 , though it is statistically insignificant.

The percentage of DNA in head parameter of follow-up sample $(84.2 \pm 6.7)$ is increased when compared to post-RT sample $3(73.2 \pm 10.3)$ with a p value less than 0.05 .

\section{D) Tail length}

Comparison of tail length parameter of all the five samples in patients with complete regression of tumour is shown in Table XII and Chart X.

\begin{tabular}{|c|c|c|c|c|c|}
\hline \multirow[t]{2}{*}{ Comet Parameters } & \multicolumn{5}{|c|}{ Mediam (IQR) } \\
\hline & Baseline & Post - RT1 & Post - RT2 & Post - RT3 & Follow - Up \\
\hline \multirow[t]{2}{*}{ Tail length $(\mu \mathrm{m})$} & 6.4 & 46.9 & 57.13 & 52.8 & 18.0 \\
\hline & $(3.0-14.1)$ & $(41.1-76.0)$ & $(44.6-67.3)$ & $(45.5-73.4)$ & $(10.8-26.0)$ \\
\hline \multirow[t]{2}{*}{$p<0.05$} & \multicolumn{5}{|c|}{ Baseline vs Post-RT1 } \\
\hline & \multicolumn{5}{|c|}{ Post-RT3 vs Follow-up } \\
\hline \multirow[t]{2}{*}{$p>0.05$} & \multicolumn{5}{|c|}{ Post-RT1 vs Post-RT2 } \\
\hline & \multicolumn{5}{|c|}{ Post-RT2 vs Post-RT3 } \\
\hline
\end{tabular}

The tail length parameter of post-RT sample 1 [46.9(41.1-76.0) $\mu \mathrm{m}]$ is increased when compared to baseline sample [6.4(3.0-14.1) $\mu \mathrm{m}]$ with a $\mathrm{p}$ value less than 0.05 .

There is no progressive increase in the tail length parameter of post-RT samples 1,2 and 3

The tail length parameter of follow-up sample [18.0(10.8-26.0) $\mu \mathrm{m}]$ is decreased when compared to postRT sample 3 [52.8(45.5-73.4) $\mu \mathrm{m}]$ with a p value less than 0.05 .

\section{E) Percentage of DNA in tail}

Comparison of percentage of DNA in tail parameter of all the five samples in patients with complete regression of tumour is shown in Table XIII and Chart XI 


\begin{tabular}{|llllll|}
\hline Comet Parameters & \multicolumn{3}{l}{ Mean \pm SD } & & \\
& Baseline & Post - RT1 & Post - RT2 & Post - RT3 & Follow - Up \\
\hline \% of DNA in tail & $13.3 \pm 5.5$ & $22.7 \pm 11.0$ & $25.7 \pm 10.2$ & $27.8 \pm 10.5$ & $15.8 \pm 6.7$ \\
\hline $\mathrm{p}<0.05$ & & & & \\
& & & & \\
$\mathrm{p}>0.05$ & Baseline vs Post-RT1 & & & \\
& Post-RT3 vs Follow-up & & \\
& Post-RT1 vs Post-RT2 & & \\
\hline
\end{tabular}

The percentage of DNA in tail parameter of post-RT sample $1(22.7 \pm 11.0)$ is increased when compared to baseline sample (13.3 \pm 5.5$)$ with a $p$ value less than 0.05 .

There is a progressive increase in the percentage of DNA in tail parameter of post-RT samples 1, 2 and 3, though it is statistically insignificant.


to post-RT sample $3(27.8 \pm 10.5)$ with a p value less than 0.05 .

Repair analysis and risk factors in complete tumour regression patients

\section{Smoking}

Comet parameters were compared in relation to smoking status among the patients with complete regression of tumour for repair analysis of DNA and the results are shown in the Table XX. 


\begin{tabular}{|c|c|c|c|c|}
\hline \multirow[t]{2}{*}{ Comet parameters } & \multirow[t]{2}{*}{ smoking } & \multicolumn{2}{|l|}{ Mean \pm SD } & \multirow[t]{2}{*}{$p$ value } \\
\hline & & Baseline & Follow-up & \\
\hline \multirow{2}{*}{$\begin{array}{l}\text { Comet } \\
\text { length }(\mu \mathrm{m})\end{array}$} & Yes & $52.1 \pm 25.0$ & $69.4 \pm 24.9$ & \multirow{10}{*}{$>0.05$} \\
\hline & No & $75.9 \pm 36.7$ & $74.8 \pm 10.1$ & \\
\hline \multirow{2}{*}{$\begin{array}{l}\text { Head } \\
\text { diameter( } \mu \mathrm{m})\end{array}$} & Yes & $46.3 \pm 23.9$ & $57.3 \pm 24.2$ & \\
\hline & No & $59.3 \pm 28.0$ & $49.8 \pm 12$ & \\
\hline \multirow[t]{2}{*}{ \% DNA in head } & Yes & $85.5 \pm 4.4$ & $84.9 \pm 7.5$ & \\
\hline & No & $89.3 \pm 7.0$ & $82.9 \pm 5.5$ & \\
\hline \multirow[t]{2}{*}{ Tail length $(\mu \mathrm{m})$} & Yes & $6.7 \pm 3.9$ & $13.3 \pm 8.6$ & \\
\hline & No & $17.5 \pm 17.9$ & $24.5 \pm 2.3$ & \\
\hline \multirow[t]{2}{*}{$\%$ DNA in tail } & Yes & $14.7 \pm 4.3$ & $15 \pm 7.5$ & \\
\hline & No & $10.7 \pm 7.0$ & $17.1 \pm 5.5$ & \\
\hline
\end{tabular}

No significant difference in repair analysis of DNA was observed between smokers and non-smokers in patients with complete regression of tumor.

\section{Alcoholic status}

Comet parameters were compared in relation to alcoholic status among the patients with complete regression of tumour for repair analysis of DNA and the results are shown in the Table XXI. 


\begin{tabular}{|c|c|c|c|c|}
\hline \multirow[t]{2}{*}{ Comet parameters } & \multirow[t]{2}{*}{ Alcoholic status } & \multicolumn{2}{|c|}{ Median \pm IQR } & \multirow[t]{2}{*}{$\mathrm{p}$ value } \\
\hline & & Baseline & Follow-up & \\
\hline \multirow{2}{*}{$\begin{array}{l}\text { Comet } \\
\text { length }(\mu \mathrm{m})\end{array}$} & Yes & $59.2 \pm 38.0$ & $69.8 \pm 9.6$ & \multirow{10}{*}{$>0.05$} \\
\hline & No & $61.1 \pm 29.6$ & $71.9 \pm 23.9$ & \\
\hline \multirow{2}{*}{$\begin{array}{l}\text { Head } \\
\text { diameter }(\mu \mathrm{m})\end{array}$} & Yes & $55.1 \pm 35.3$ & $54.0 \pm 14.6$ & \\
\hline & No & $49.3 \pm 22.2$ & $54.8 \pm 23.1$ & \\
\hline \multirow[b]{2}{*}{ \% DNA in head } & Yes & $87.0 \pm 4.6$ & $84.6 \pm 5.5$ & \\
\hline & No & $86.8 \pm 6.1$ & $84.0 \pm 7.5$ & \\
\hline \multirow{2}{*}{ Tail length $(\mu \mathrm{m})$} & Yes & $5.7 \pm 3.7$ & $16.8 \pm 9.4$ & \\
\hline & No & $12.5 \pm 13.4$ & $17.8 \pm 9.4$ & \\
\hline \multirow{2}{*}{$\%$ DNA in tail } & Yes & $13.0 \pm 4.6$ & $15.4 \pm 5.5$ & \\
\hline & No & $13.4 \pm 6.1$ & $15.9 \pm 7.4$ & \\
\hline
\end{tabular}

No significant difference in repair analysis of DNA was observed between alcoholics and others in patients with complete tumor regression

\section{Tobacco chewing status}

Comet parameters were compared in relation to tobacco chewing status among the patients with complete regression of tumour for repair analysis and the results are shown in the Table XXII 


\begin{tabular}{|c|c|c|c|c|}
\hline \multirow[t]{2}{*}{ Comet parameters } & \multirow[t]{2}{*}{ Tobacco chewing } & \multicolumn{2}{|c|}{ Median \pm IQR } & \multirow[t]{2}{*}{$\mathrm{p}$ value } \\
\hline & & Baseline & Follow-up & \\
\hline \multirow{2}{*}{$\begin{array}{l}\text { Comet } \\
\text { length }(\mu \mathrm{m})\end{array}$} & Yes & $53.1 \pm 23.4$ & $70.3 \pm 22.5$ & \multirow{10}{*}{$>0.05$} \\
\hline & No & $87.9 \pm 44$ & $75.3 \pm 82.5$ & \\
\hline \multirow{2}{*}{$\begin{array}{l}\text { Head } \\
\text { diameter }(\mu \mathrm{m})\end{array}$} & Yes & $45.9 \pm 20.6$ & $54.0 \pm 22.3$ & \\
\hline & No & $69.5 \pm 36.6$ & $56.9 \pm 14.7$ & \\
\hline \multirow[b]{2}{*}{ \% DNA in head } & Yes & $87.1 \pm 5.8$ & $84.6 \pm 7.4$ & \\
\hline & No & $86.0 \pm 5.3$ & $83.0 \pm 3.8$ & \\
\hline \multirow{2}{*}{ Tail length $(\mu \mathrm{m})$} & Yes & $8.0 \pm 6.8$ & $17.2 \pm 10.1$ & \\
\hline & No & $19.9 \pm 12.2$ & $18.8 \pm 4.4$ & \\
\hline \multirow[b]{2}{*}{$\%$ DNA in tail } & Yes & $13.1 \pm 5.8$ & $15.4 \pm 7.4$ & \\
\hline & No & $14.0 \pm 5.3$ & $17.0 \pm 3.8$ & \\
\hline
\end{tabular}

No significant difference in repair analysis of DNA was observed between tobacco users and others in patients with complete regression of tumor

\section{Discussion}

Around 2,00,000 cases of Head and Neck Carcinoma are reported every year in India. Concurrent chemoradiation forms the mainstay of treatment for locally advanced cancers. Chemo-radiation induces DNA damage to the target cells as well as some of the normal cells. As the monitoring of repair of target tissue is practically not possible, lymphocytes are used as a surrogate marker. DNA repair capacity is measurable in various cell types as it has a genetic predisposition (7). In earlier studies, Comet assay has been documented as a reliable parameter to assess the DNA damage (8).

\section{I.ANALYSIS OF BASELINE CHARACTERISTICS}

In the present study, most of the patients were distributed in the age group of 50-59 years (Table I). The total number of males were more when compared to females (Table II).Risk factors like smoking, alcohol consumption and tobacco chewing were documented among the study group (Table IV). Most of the males were found to be associated with all the three risk factors whereas the females mostly with that of tobacco chewing.

\section{II.ANALYSIS OF BASELINE DNA DAMAGE}


Previous studies show that there is a baseline DNA damage in the patients with various carcinoma prior to radiotherapy (9). The observations in this study are:

- Increase in baseline DNA damage is noted as the age increases (Table V).

- Patients with greater than one risk factor are found to have more baseline DNA damage when compared to the others (Table VI \& Chart V).

\section{ANALYSIS OF POST - RT DNA DAMAGE}

The second, third and fourth samples were collected 2 hours after the 10th, 20th and 30th fraction of radiation respectively. MarijaGamulin et al., observed an increase in the DNA damage in the post radiotherapy period when compared to that of pre radiotherapy and this study findings also confirm the same (4).Significant sequential increase in the DNA damage was observed in the percentage of DNA in tail parameter throughout the course of the radiation (Table XIII \& Chart XI).Patients were followed-up for one month after the completion of the treatment and the tumor response was analyzed. The follow-up samples showed a decrease in the comet length and tail length and the percentage of DNA in tail parameters when compared to the post radiotherapy values though the values had not returned to the baseline values (Table VIII) and this agrees the findings of David et al (8).

\section{REPAIR ANALYSIS}

In a study by Gamulin $M$ et al, who assessed radiotherapy induced DNA damage using comet assay in oropharyngeal cancer patients, the sample taken after the completion of the therapy showed decreased DNA damage when compared to the baseline level(8). Our study did not show the values returning to the baseline level. This finding is in contrast to that of Gamulin $M$ et al. While Gamulin et al. recorded the post radiation values after six months of radiotherapy, our study recorded it one month following the completion of radiation. This could explain the possible reason for the follow-up sample values were not returning to the baseline values, or it could be the patient's general condition mainly determining the repair capacity and thereby hindering the return of the values.

\section{RISK FACTORS AND COMET PARAMETERS}

\section{SMOKING:}

Few authors studied the DNA damage in the smokers and the nonsmokers (Leanderson et al., Soylemez et al.). They observed higher DNA damage in the smokers than the non-smokers $(10,11)$. In our present study, the baseline values were higher in the patients with smoking when compared to the nonsmokers but not statistically significant. The repairing capacity of DNA is less in the smokers when compared to the non-smokers within the sub - group 2(Table XXIII).

\section{ALCOHOL CONSUMPTION:}


In the present study, most of the alcohol consumption groups were males. The repairing capacity of DNA is less in the alcoholics when compared to the non-alcoholics as evident by the tail length and percentage of DNA in tail parameters within the patients of sub-group 2 (Table XXIV). This agrees with the findings of Rulten et al., who demonstrated that DNA damage is induced by the consumption of alcohol(12).

\section{TOBACCO CHEWING:}

Tobacco chewing is documented as one of the major risk factors in the Indian population due to the cultural and ethnic variation. The comet parameters showed an increase in baseline values in the tobacco chewers compared to the tobacco non-chewers which agrees with the findings of Pfeifer et al(13).

\section{Conclusion}

Patients with locally advanced head and neck cancers with complete tumor response following radiotherapy show a sequential increase in the DNA damage. The co-existing risk factors and old age may increase the baseline DNA damage in the patients with head and neck carcinoma. The repair mechanism is dependent on the patient's general condition, risk factors and also the biology of the tumor.

\section{Declarations}

\section{Ethical approval and consent of the participant:}

The study was subjected to the ethical clearance and approved by the Institute Ethics Committee [Ref No: ECR/342/Inst/PY/2013]. Informed consent was taken from each participant of the study.

\section{Consent for publication:}

Informed consent was taken from all the participants for the publication of the results of the study. The participants were also assured that their identity would not be revealed and anonymity would be maintained

\section{Availability of data and materials:}

The dataset analysed during the current study are cited as references within the square brackets in the manuscript and the corresponding details are provided under the reference section.

Competing interest: There is no conflict of interest in this study

Funding: No funding was received

\section{Author contribution:}

Dr. Sivakumar M - conceptualization, investigation, methodology, writing, analysis, editing 
Dr. Ariyanachi K-editing, writing

Acknowledgement: We are really grateful to all the participants of this study for their kind co-operation and patience

\section{Author information:}

\section{Dr. Sivakumar M -}

Assistant Professor, Anatomy,

Thiruvannamalai Medical College and Hospital, Tamil Nadu,

India.

Mobile: 9500359432

Mail id:drsivakmc@gmail.com

\section{Dr. Ariyanachi K}

Dr. Ariyanachi K,

Assistant Professor, Anatomy,

AllMS, Hyderabad,

India.

Mail id: ariyan.mahi@gmail.com

\section{References}

1. Mishra A, Meherotra R. Head and neck cancer: global burden and regional trends in India. Asian Pac J Cancer Prev. 2014,15(2):537-50.

2. Takiar R, Nadayil D, Nandakumar A.Projections of number of cancer cases in India (2010-2020) by cancer groups. Asian Pac J Cancer Prev. 2010,11(4):1045-9

3. Udumudi A, Jaiswal M, Rajeswari N, Desai N, Jain S, Balakrishna N, Rao KV, Ahuja YR. Risk assessment in cervical dysplasia patients by single cell gel electrophoresis assay: a study of DNA damage and repair. Mutat Res. 1998, 412(2):195-205.

4. Gamulin M, Garaj-Vrhovac V, Kopjar N. Evaluation of DNA damage in radiotherapy-treated cancer patients using the alkaline comet assay. Coll Antropol. 2007,31(3):837-45.

5. Popanda O, Ebbeler R, Twardella D, Helmbold I, Gotzes F, Schmezer P, Thielman HW, von Fournier D, Haase W, Sautter-Bihl ML, Wenz F, Bartsch H, Chang-Claude J. Radiation-induced DNA damage and 
repair in lymphocytes from breast cancer patients and their correlation with acute skin reactions to radiotherapy. Int J Radiat Oncol Biol Phys. 2003,55(5):1216-25.

6. De Ruyck K, Van Eijkeren M, Claes K, Morthier R, De Paepe A, Vral A, De Ridder L, Thierens H. Radiation-induced damage to normal tissues after radiotherapy in patients treated for gynecologic tumors: association with single nucleotide polymorphisms in XRCC1, XRCC3, and OGG1 genes and in vitro chromosomal radiosensitivity in lymphocytes. Int J Radiat Oncol Biol Phys. 2005,62(4):1140-

7. Rusin P, Walczak A, Zwierzchlejska A, Olszewski J, Morawiec-Bajda A, Kaczmarczyk D, Kusmierczyk K, Garncarek P, Pytel D, Sliwinński T, Majsterek I. DNA damage and repair of head and neck cancer cells after radio- and chemotherapy. Z Naturforsch C. 2009,64(7-8):601-10

8. Terris DJ, Ho EY, Ibrahim HZ, Dorie MJ, Kovacs MS, Le QT, Koong AC, Pinto HA, Brown JM. Estimating DNA repair by sequential evaluation of head and neck tumor radiation sensitivity using the comet assay. Arch Otolaryngol Head Neck Surg.2002:698-702.

9. Nascimento PA, da Silva MA, Oliveira EM, Suzuki MF, Okazaki K. Evaluation of radioinduced damage and repair capacity in blood lymphocytes of breast cancer patients. Braz J Med Biol Res. 2001,34(2):165-76.

10. Leanderson P, Tagesson C. Cigarette smoke-induced DNA damage in cultured human lung cells: role of hydroxyl radicals and endonuclease activation. Chem Biol Interact. 1992,81(1-2):197-208

11. Soylemez E, Kayaaltı Z, Aliyev V, Soylemezoglu T. Effect of cigarette smoking on DNA damage according to nine comet assay parameters in female and male groups.

AnkUniversitesiTıpFakultesiMecm. 2012,65:39-46.

12. Rulten SL, Hodder E, Ripley TL, Stephens DN, Mayne LV. Alcohol induces DNA damage and the Fanconi anemia D2 protein implicating FANCD2 in the DNA damage response pathways in brain. Alcohol Clin Exp Res. 2008,32(7):1186-96.

13. Pfeifer GP, Denissenko MF, Olivier M, Tretyakova N, Hecht SS, Hainaut P.Tobacco smoke carcinogens, DNA damage and p53 mutations in smoking-associated cancers. Oncogene. 2002,21(48):7435-51. 